\title{
Idiopathic pulmonary fibrosis: diagnostic pitfalls and therapeutic challenges
}

\author{
Paolo Spagnolo*, Roberto Tonelli, Elisabetta Cocconcelli, Alessandro Stefani and Luca Richeldi
}

\begin{abstract}
Idiopathic pulmonary fibrosis (IPF), the most common of the idiopathic interstitial pneumonias, is a devastating condition that carries a prognosis worse than that of many cancers. As such, it represents one of the most challenging diseases for chest physicians. The diagnostic process is complex and relies on the clinician integrating clinical, laboratory, radiologic, and/or pathologic data. Therefore, a close collaboration between chest physicians, radiologists, and pathologists experienced in the diagnosis of interstitial lung diseases (ILDs) is necessary in order to minimize diagnostic uncertainty. Similarly, the management of IPF continues to pose major difficulties. However, while there are no proven effective therapies for IPF beyond lung transplantation, recent trials of novel agents suggest that pharmacological treatment may retard the progression of the disease. In this regard, enrolment of patients into clinical trials is considered the "best current practice"by the most recent guidelines as it offers IPF patients the chance to receive new agents that may be more effective than current therapies. A more recent trend focusing on improving quality of life in IPF patients has also been gaining ground.

The diagnosis and management of IPF remains a constant challenge for even the most experienced of clinicians. However, a multidisciplinary approach to this complex disease is steadily improving diagnostic accuracy, while recent advances in the pharmacological therapy offer the genuine promise of future treatments for this devastating disease.
\end{abstract}

Keywords: Clinical trials, Idiopathic pulmonary fibrosis, Interstitial lung disease, Pulmonary fibrosis, Treatment

\section{Introduction}

Idiopathic pulmonary fibrosis (IPF) is a progressive fibrosing interstitial pneumonia of unknown cause, limited to the lung and associated with the histopathological (evidence of patchy involvement of lung parenchyma by fibrosis/architectural distortion, honeycombing in a predominantly subpleural/paraseptal distribution, presence of fibroblast foci) and/or radiological (subpleural, basalpredominant honeycombing and reticular abnormality, with or without traction bronchiectasis) pattern of usual interstitial pneumonia (UIP) [1]. The disease carries a dismal prognosis with a median survival time - in retrospective longitudinal studies - of 2 to 3 years from the time of diagnosis [2-5]. The diagnosis of IPF is established in the presence of a UIP pattern on highresolution computed tomography (HRCT) of the chest and/or in the surgical lung biopsy (SLB) specimen in the

\footnotetext{
* Correspondence: paolo.spagnolo@unimore.it

Center for Rare Lung Disease, University Hospital of Modena, Via del Pozzo 71, 41124, Modena, Italy
}

\section{() Biomed Central}

appropriate clinical setting (commonly a current or exsmoker male of $>60$ years of age) and after the exclusion of all known causes of pulmonary fibrosis [1]. However, the diagnosis may not be straightforward; in fact, IPF belongs to a large family which is estimated being populated by more than 200 different entities, known as interstitial lung diseases (ILDs), many of which have features similar to IPF [6]. One recent study estimated the prevalence of all ILDs in the US at about 500,000 [7]. Not surprisingly, $>50 \%$ of these patients are initially misdiagnosed with other forms of respiratory illness [8].

Diagnosing IPF in daily practice may be challenging and there is often a significant delay between the first manifestations of the disease - typically a combination of dyspnea on exertion and dry cough - and its correct diagnosis [9]. Moreover, a sufficient level of diagnostic confidence is not reached in a sizeable proportion of cases. Disease management is similarly challenging. To date, only one drug has been approved for use in Europe, India and Japan and there are no licensed medical 
therapies in the US: more importantly, no medical therapy has proven to improve overall survival in patients with IPF [10]. As such, the only care options that are endorsed by the recent evidence-based guidelines are lung transplantation and enrolment in a clinical trial [1]. However, less than one-third of a large patient cohort evaluated at a center with extensive expertise in ILD could realize these currently recommended treatment options, highlighting the need for other management approaches [11].

This review focuses on current diagnostic and therapeutic challenges in IPF. Timely diagnosis and early referral of patients to centers with specific expertise may lead to more optimal disease management.

\section{Diagnostic challenges \\ Delay in diagnosis}

Suspicion of IPF often arises several months after the initial manifestations of the disease. In fact, dry cough and exertional dyspnea - the most common presenting symptoms - tend to be overlooked and wrongly attributed to smoking habits or aging. Uncertainties, thus diagnostic delay, may be due to a number of reasons. Sometimes, patients may be too sick to undergo surgical, although relatively non-invasive, procedures and this may preclude obtaining tissue samples, which are critical for the final diagnosis in a sizeable proportion of cases. Conversely, in community centers the diagnostic delay could be due to the radiologist or pathologist insufficient experience with ILD. Nevertheless, although the overall accuracy of a diagnosis of IPF in expert centers has been reported to be good (87\%), even in this setting the level of agreement within experts is fair to moderate [12]. Significant disagreement between academic and communitybased physicians with regard to the final diagnosis also exists, with community-based physicians being more likely to assign a final diagnosis of IPF compared with academic physicians, highlighting the importance of referring patients with suspected IPF to centers with expertise in ILD [13].

\section{Ruling out alternative diagnoses}

Being the disease "idiopathic" by definition, the diagnosis of IPF requires the exclusion of all known causes of ILD. Because the number of potential "mimickers" of IPF is high, this step is crucial.

\section{Familial pulmonary fibrosis}

Familial pulmonary fibrosis (FPF), the occurrence of IPF in two or more members of the same family, accounts for less than 5\% of total IPF cases $[14,15]$. Familial and sporadic IPF are clinically and histologically indistinguishable, although familial forms may develop at an earlier age [14] and display different patterns of gene transcription [16]. Cigarette smoking appears to be a risk factor for the development of FPF, suggesting that environmental/occupational exposures may accentuate genetic risk and that gene-environment interactions may be critical in IPF pathogenesis. Another remarkable finding is the pathologic heterogeneity within family members. In fact, while $50 \%$ of the families have a "uniform" diagnosis of UIP/IPF, the remaining $50 \%$ display radiological or pathologic features suggestive of a different IIP in at least one affected family member [17].

\section{Hypersensitivity pneumonitis}

Patients with ILD should be thoroughly investigated for possible HP since chronic forms - commonly caused by prolonged exposure to low antigen levels - may mimic IPF both clinically and radiologically [18]. Bronchoalveolar lavage (BAL) showing a lymphocytosis of $40 \%$ or greater, mainly sustained by $\mathrm{CD} 8+\mathrm{T}$ lymphocytes, strongly suggests the diagnosis of chronic HP [19]. Search for possible exposures should cover occupational and non-occupational causes of HP with particular attention to domestic mold and fungal and bacterial agents. If diagnostic uncertainty persists the diagnosis requires histologic confirmation, although chronic forms of HP may display a UIP pattern. Nonetheless, recognition of the causal antigen is critical not only for the diagnosis but also for the treatment as avoidance of further exposure is essential [20].

\section{Connective tissue disease}

Connective tissue disease (CTD) can present with a UIP pattern [21] and ILD has been described as the sole clinical manifestation of some of these conditions $[22,23]$. Because IPF is rare before the age of 50, the index of suspicion for an underlying CTD should be high in the presence of young patients, especially female, since patients without clinical or serologic features at presentation may subsequently manifest overt features of an underlying CTD that was subclinical at the time of first presentation. Conversely, patients with IPF may have positive antinuclear antibodies (ANA) at low titers and/or borderline positive rheumatoid factor without any other clinical features of CTD [24]. Such patients should be carefully screened for signs and symptoms of connective tissue disease, e.g., arthritis, Raynaud's phenomenon, skin changes or abnormal esophageal motility. If repeat serologic and clinical evaluation during follow up confirms the development of a CTD, the diagnosis should be revised, given the therapeutic and prognostic implications [1].

\section{Asbestosis}

The differential diagnosis between asbestosis and IPF may not be straightforward owing to the radiological and histopathological similarities between these two 
entities [25]. Since the aetiology, behaviour and prognosis of these two conditions may differ significantly, an accurate differentiation is strictly needed, also considering that patients with asbestosis may be eligible for legal compensation [26]. Chest HRCT features of asbestosinduced pulmonary fibrosis and IPF may overlap in some cases and look similar at first sight [27]. Emphasis must be placed on the presence of pleural involvement (e.g., pleural plaques or diffuse pleural thickening), which is almost universal in asbestosis [26]. However, relying on pleural disease alone may be an oversimplification: in fact, an individual previously exposed to asbestos remains as susceptible to non-asbestos-induced fibrotic lung diseases (including IPF) as the general population; on the other hand, diffuse pleural thickening may be due to other causes [28]. Histologically, some cases of asbestosis resemble UIP - while others resemble fibrotic nonspecific interstitial pneumonitis (NSIP) although the presence of asbestos bodies may permit to differentiate asbestosis from other ILDs [27]. In addition, fibroblastic foci, a pathologic hallmark of IPF, are infrequent in asbestosis [27]. Finally, asbestosis is almost invariably characterized by mild fibrosis of the visceral pleura, a rare feature in IPF. If uncertainty persists, specific fibre analysis may be necessary to determine the aetiology of the fibrotic process [27].

\section{Sarcoidosis}

Without an adequate review of a patient's medical history and past relevant imaging data, fibrotic sarcoidosis (radiographic stage IV; $[29,30]$ ) may be overlooked. HRCT features of pulmonary sarcoidosis include upper lobe-predominant small nodules distributed along the broncho-vascular bundle and pleural membranes, thickening of the interlobular septa and mediastinal lymphadenopathy. However, subpleural bibasal honeycombing, cysts and traction bronchiectasis mimicking a UIP pattern may rarely be observed [31-33]. Findings in support of a diagnosis of sarcoidosis include a history of skin or ocular lesions, hilar or mediastinal lymphadenopathy, chronic fatigue, and elevated serum levels of angiotensin-converting enzyme (ACE) [34-36]. Conversely, chest HRCT appearances compatible with sarcoidosis may prove to be atypical manifestations of IPF [37].

Table 1 lists the main radiologic and histopathologic features that help differentiate IPF from other fibrotic lung diseases.

\section{Special conditions}

IPF presenting as acute exacerbation of IPF

The clinical course of IPF is most commonly characterized by a slowly progressive decline in lung function and worsening dyspnea leading to death within several years of diagnosis [38]. However, IPF may also present, though rarely, acutely in patients without a known history of chronic lung disease [39]. In such cases, lung biopsy (often difficult to obtain due to patient clinical conditions) shows diffuse alveolar damage (DAD) superimposed on a UIP pattern, similar to what is seen in acute exacerbations of IPF (AE-IPF). AE-IPF is defined as an acute unexplained respiratory deterioration (worsening dyspnea, increased cough and worsening of gas exchange parameters) within one month and the appearance of new parenchymal opacities on chest radiograph or HRCT in the absence of alternate causes, such as infection, pulmonary embolism or heart failure [40]. The correct diagnosis may remain uncertain if the patient conditions contraindicate a confirmatory lung biopsy; as such, these patients are often misdiagnosed

Table 1 Radiologic and histopathologic features suggestive of a fibrotic lung disease other than IPF

\begin{tabular}{|c|c|c|c|c|}
\hline & $\begin{array}{l}\text { Hypersensitivity } \\
\text { pneumonitis }\end{array}$ & Connective tissue disease & Asbestosis & Sarcoidosis \\
\hline \multirow[t]{3}{*}{$\begin{array}{l}\text { Radiologic } \\
\text { features }\end{array}$} & $\begin{array}{l}\text { Areas of decreased } \\
\text { attenuation }\end{array}$ & $\begin{array}{l}\text { Bronchiectasis far from fibrotic } \\
\text { areas }\end{array}$ & $\begin{array}{l}\text { Plaques and/or } \\
\text { significant pleural } \\
\text { thickening }\end{array}$ & $\begin{array}{l}\text { Fibrosis, linear opacities and traction } \\
\text { bronchiectasis predominantly in the perihilar } \\
\text { regions and upper lobes }\end{array}$ \\
\hline & $\begin{array}{l}\text { Centrilobular nodules } \\
\text { Mid-upper lobe predominance }\end{array}$ & $\begin{array}{l}\text { Signs of pulmonary } \\
\text { hypertension disproportionate } \\
\text { to the extent of fibrosis }\end{array}$ & Limited extent & $\begin{array}{l}\text { Conglomerate masses of fibrosis in the } \\
\text { posterior part of the lungs }\end{array}$ \\
\hline & & $\begin{array}{l}\text { Pleural or pericardial effusion } \\
\text { Oesophagus or bone } \\
\text { abnormalities }\end{array}$ & & $\begin{array}{l}\text { Small well-defined nodules with a } \\
\text { perilymphatic distribution }\end{array}$ \\
\hline \multirow{4}{*}{$\begin{array}{l}\text { Histological } \\
\text { features }\end{array}$} & Cellular interstitial pneumonia & Dense perivascular collagen & Pleural abnormalities & \multirow{4}{*}{$\begin{array}{l}\text { Non-caseating granulomas with a } \\
\text {-characteristic perilymphatic distribution }\end{array}$} \\
\hline & $\begin{array}{l}\text { Multinucleated giant cells or } \\
\text { granulomas situated around } \\
\text { bronchioles }\end{array}$ & Extensive pleuritis & Asbestos bodies & \\
\hline & & $\begin{array}{l}\text { Lymphoid aggregates with } \\
\text { germinal center formation }\end{array}$ & $\begin{array}{l}\text { Bronchial wall } \\
\text { fibrosis }\end{array}$ & \\
\hline & & $\begin{array}{l}\text { Prominent plasmacytic } \\
\text { infiltration }\end{array}$ & $\begin{array}{l}\text { Fibroblastic foci } \\
\text { infrequent }\end{array}$ & \\
\hline
\end{tabular}


as acute interstitial pneumonia or acute respiratory distress syndrome.

\section{Unclassifiable ILD}

In some cases, even at the end of an accurate diagnostic work-up, the nature of the fibrotic process may remain unclear. Possible causes of diagnostic failure could be either technical or atypical manifestations of the disease. For instance, a biopsy taken from the "wrong" area may provide normal lung tissue, indiscernible end-stage lung or a sample that does not meet diagnostic criteria for any specific ILD. In such cases, the biopsy will not be diagnostic.

\section{Challenges in obtaining a surgical lung biopsy}

In patients whose HRCT does not demonstrate a UIP pattern, a surgical lung biopsy (SLB) is necessary to make a definitive diagnosis. From a technical point of view, the following aspects should be considered: type of surgical approach, side of operation, target areas for the biopsy and number of biopsies. The diagnostic yield from surgical lung biopsies obtained from video-assisted thoracoscopy (VATS) and open thoracotomy are similar, although VATS is associated with lower morbidity and length of stay than open thoracotomy, thus representing the procedure of choice [1], while a lateral "muscle sparing" thoracotomy should be limited to cases with strong pleural adhesions, which makes VATS not practicable. Target areas for biopsy should be selected on the basis of HRCT features and discussed with the radiologist. Ideally, biopsy specimens should be taken neither from the most fibrotic areas nor from normal areas. In patients with suspected IPF, biopsies should be obtained from multiple lobes. In fact, specimens obtained from different segments may display discordant histological patterns, although cases with coexisting UIP pattern and fibrotic NSIP pattern (discordant UIP) appear to behave similarly to those with UIP pattern in all lobes (concordant UIP) $[41,42]$. If both lungs are equally affected, SLB is commonly performed in the left lung, because lung margins are thinner and easy to resect; in addition, right lung is usually functionally dominant, thus deflating the left lung may allow the patient to better tolerate singlelung ventilation. After SLB, a morbidity of 9-20\% and a mortality of $0-5 \%$ have been reported, this disagreement likely reflecting the different types of patients included in the SLB series [43]. The decision whether or not to obtain a SLB must be tailored to the clinical situation of the individual patient and after a careful evaluation of benefits and risks. Thus, while in younger patients (potential candidates to lung transplantation) an histological confirmation of the diagnosis is strongly recommended, in older patients with severe physiologic impairment or substantial comorbidity, the risks of SLB may outweigh the benefits of establishing a secure diagnosis of IPF.

Table 2 summarizes the main challenges in diagnosing IPF.

\section{Therapeutic challenges \\ Pharmacological therapies \\ Improving survival}

IPF is a disease with a poor prognosis that appears unchanged over the past decade: the median survival in non-transplanted patients is around 3.5 years after diagnosis $[1,11]$. Therefore, at present, improving survival appears the most difficult goal to achieve [44]. In fact, none of the studies that aimed at showing an effect on survival either as primary or secondary endpoint showed evidence of efficacy in this respect [45]. This could be due to a number of factors, including disease heterogeneity, concomitant conditions influencing clinical response, incomplete knowledge of disease pathogenetic mechanisms, real lack of efficacy of the compounds tested thus far, need to tackle more than one fibrogenic pathway, which in turn, would require a multi-drug regimen, or case selection, since clinical trials have often included highly selected patients while many are excluded by virtue of their age, disease severity, or comorbid conditions. In this regard, it is noteworthy that of IPF patients evaluated at a referral US centre over a period of 5 years less than one third qualified for enrolment in a clinical trial, despite the availability and contiguity of multiple clinical trials [11]. Conversely, treatments initially thought to slow the decline of lung function [46] or reduce mortality in patients experiencing acute exacerbation [47] and which received a weak recommendation against their use by the most recent guidelines [1] have subsequently been shown not only to be ineffective but even harmful in patients with IPF $[48,49]$. Specifically, an efficacy and safety interim analysis of the PANTHER-IPF (Prednisone, Azathioprine, and N-acetylcysteine: A Study That Evaluates Response in IPF) study, in which patients

\section{Table 2 Diagnostic challenges in IPF}

\begin{tabular}{l}
\hline Delay in diagnosis \\
\hline Ruling out alternative diagnoses \\
\hline Familial pulmonary fibrosis \\
\hline Hypersensitivity pneumonitis \\
\hline Connective Tissue Disease \\
\hline Asbestosis \\
\hline Sarcoidosis \\
\hline Special conditions \\
\hline IPF presenting as acute exacerbation of IPF \\
\hline Unclassifiable ILD \\
\hline Obtaining a surgical lung biopsy
\end{tabular}


with mild-to-moderate lung function impairment were randomized in a 1:1:1 ratio to prednisone, azathioprine and NAC (combination therapy), NAC alone or placebo, revealed that the combination therapy, as compared to placebo, was associated with a statistically significant increase in all-cause mortality (11\% vs. $1 \%)$, all-cause hospitalizations $(29 \%$ vs. $8 \%)$, and treatment-related severe adverse events (31\% vs. 9\%) [49], thus providing robust evidence against the use of this combination of drugs in patients with IPF.

There is a growing appreciation that distinct phenotypes exist within what is currently regarded as IPF. Clinical variants include a temporal spectrum of disease behavior that ranges from a rapid, including acute exacerbations, to a slowly protracted pattern of progression. Interestingly, this latter "survivor" group is equally distributed among disease severity groups [11]. A survival "tail" has been described in older publications but it has been commonly attributed to the inclusion of patients with diseases other than IPF (i.e., NSIP); having excluded alternative diagnoses, the observed survival "tail" in IPF appears to be real [11]. These patients should not be included in clinical trials assessing survival as slow progressors are less likely to respond to any given drug, thus leading to false negative results.

\section{Improvement of clinically meaningful outcomes}

Drugs evaluated to date in IPF have failed to demonstrate an effect on survival [1]. However, recent data suggest that treatment may impact on a number of clinically meaningful outcomes. Forced vital capacity (FVC) is the most commonly used physiological measurement and primary endpoint in clinical trials in IPF. In fact, changes in a patient's FVC over time (whether analyzed continuously or categorically as above or below a threshold value) have been correlated with survival time in multiple large cohorts of patients with IPF $[1,50]$. Recently, in a 12-month, phase 2 trial, BIBF 1120 - an intracellular tyrosine kinase inhibitor - has been shown to reduce by $68 \%$ the annual rate of decline in $\mathrm{FVC}$ as compared with placebo in patients with IPF (0.06 liters vs. 0.19 liters) [51]. Similarly, BIBF 1120 was associated with improved health-related quality of life and reduced frequency of acute exacerbations, which, in turn, are associated with rapid disease progression, severe and abrupt decline in FVC, and high mortality.

\section{Treatment of concomitant conditions}

There is an increasing awareness of complications and comorbidities frequently associated with IPF [1] but it is unknown whether they are related to the underlying pathobiology of IPF or whether they simply reflect concurrent diseases of aging. Likewise, it is unclear whether IPF patients should be screened for these conditions or whether treatment of concomitant conditions affects disease outcome, although, their presence influences both the eligibility of patients for lung transplants and their survival while on the waiting list. In addition, comorbidities and the medications prescribed for them can often contribute to symptoms, thus hampering diagnosis and treatment [52].

Common concomitant conditions include pulmonary hypertension $(\mathrm{PH})$, vascular or coronary artery disease, gastroesophageal reflux disease, obesity, diabetes, emphysema, and obstructive sleep apnoea [1]. PH is common in IPF and is associated with lower diffusing capacity of carbon monoxide $\left(\mathrm{DL}_{\mathrm{CO}}\right)$, shorter walk distance, desaturation during exercise and increased risk of death [38]. In a retrospective study of IPF patients undergoing pretransplantation right heart catheterization, one-year mortality rates were higher in patients with $\mathrm{PH}(28.0 \%$ vs. $5.5 \%$ amongst patients without $\mathrm{PH}$ ) - with mortality risk linearly correlating with mean pulmonary artery pressure [53]. Higher pulmonary vascular resistance and $\mathrm{PH}$ are also likely to account for the poor prognosis observed in patients with combined pulmonary fibrosis and emphysema [54]. In addition, recent evidence suggests that $\mathrm{PH}$ is associated with the development of acute exacerbations and, in turn, with poor prognosis [55]. Whether targeting of $\mathrm{PH}$ with medications approved for the treatment of pulmonary arterial hypertension (PAH) has any utility in the context of IPF remains unclear. In a small open label trial sildenafil - an oral phosphodiesterase 5 inhibitor - improved 6-minute-walk distance and pulmonary hemodynamics without increasing shunt flow or worsening oxygenation [56]. However, a subsequent large multicenter, randomized, double-blind, placebocontrolled study did not meet the primary end-point (change of $20 \%$ in 6-minute-walk distance [6MWD] at 12 weeks), although statistically significant differences were observed in dyspnea, $\mathrm{PaO}_{2}, \mathrm{DL}_{\mathrm{CO}}$, and quality of life favouring sildenafil [57]. Bosentan - an endothelin $(\mathrm{ET})_{\mathrm{A}}$ and $\mathrm{ET}_{\mathrm{B}}$ receptor antagonist - has also been studied in IPF. Based on a non-predefined subset analysis of a smaller study suggesting that bosentan may prevent disease progression in patients that had undergone a diagnostic surgical lung biopsy [58], a larger prospective, double-blind, placebo-controlled trial was conducted. Unfortunately, the primary endpoint (time to IPF worsening or death up to end of the study) was not met [59]. Similarly, a randomized, double-blind, placebocontrolled trial of ambrisentan - a selective antagonist of the $(\mathrm{ET})_{\mathrm{A}}$ receptor - has been prematurely stopped following an interim analysis indicating lack of efficacy (http://www.gilead.com/pr, December 22 2010).

Gastroesophageal reflux disease (GERD) is another common comorbidity in patients with IPF (prevalence of approximately 90\%), and the likelihood of having both IPF and GERD increases in patients $>60$ years of age [60]. 
Patients with IPF and GERD are at higher risk for hospitalizations from any cause as well as from respiratory illness, thus suggesting that recurrent epithelial injury caused by microaspiration of gastric juice and contents may causes alveolar damage and pulmonary fibrosis [61]. The prevalence of microaspiration in patients with IPF is not known, and it is not clear whether microaspiration represents an intrinsic risk factor or causes acute exacerbations of IPF. However, in a recent uncontrolled retrospective study the reported use of GERD medications was associated with longer survival in patients with IPF, supporting the hypothesis that GERD and chronic microaspiration may play important roles in the pathobiology of IPF [62].

Coronary artery disease (CAD) is more prevalent in IPF patients compared to a similarly matched chronic obstructive pulmonary disease (COPD) group; this association, which appears to be independent of common CAD risk factors, carries a worse prognosis $[63,64]$.

At present there are no solid, prospective data on which to make definitive recommendations for treatment of concomitant conditions in patients with IPF.

\section{Management of acute exacerbations of IPF}

Acute exacerbations of IPF (AE-IPF) are, by definition, idiopathic. Therefore, known causes of acute deterioration, such as pulmonary embolism, congestive heart failure, pneumothorax and infection need to be thoroughly searched for and excluded. Based on data derived from recent randomized clinical trials, the yearly incidence of AE-IPF is between 10 and $15 \%$ of all patients $[51,65,66]$. The prognosis of AE-IPF is poor, with mortality ranging from $78 \%$ to $96 \%$ [67]. Although current guidelines recommend the use of high-dose corticosteroids, pharmacological treatment of AE-IPF is largely empiric and usually consists of intravenous corticosteroids up to a gram per day, variably combined with immunosuppressive drugs. At present, there are no controlled clinical trials on which to judge efficacy of this therapeutic strategy and specific recommendations regarding dosage, route and duration of therapy cannot be made. Many of the patients experiencing acute deterioration require intensive care treatment, particularly when respiratory failure is associated with hemodynamic instability, significant co-morbidities or severe hypoxemia. However, mortality during hospitalization is high [68]. In addition, patients with end-stage interstitial lung disease are difficult to ventilate and rarely successfully weaned from mechanical ventilation [69-71]. Thus, while the decision not to ventilate an IPF patient with acute respiratory failure is a tricky one, mechanical ventilation should be introduced only after carefully weighing the patient's long-term prognosis and, whenever possible, the patient's wishes. However, current guidelines discourage the use of mechanical ventilation in patients with respiratory failure secondary to IPF [1].

\section{Non-pharmacological interventions}

\section{Timely referral to a tertiary care center}

IPF is often initially misdiagnosed - at least until physiological and imaging data suggest the presence of an interstitial lung disease - leading to delay in accessing appropriate care. This point is not trivial in a disease with a median survival of 3 years after diagnosis. In a prospective cohort study of 129 IPF patients Lamas and coworkers showed that delayed access to a tertiary care center (defined as time from the onset of dyspnea to the date of initial evaluation at a tertiary care center) is associated with a higher risk of death independent of disease severity [72]. In turn, a delay in receiving a correct diagnosis of IPF might lead to initiation of ineffective or harmful interventions [49] and may delay evaluation for lung transplantation and inclusion in clinical trials [73]. Early referral to a center with specific expertise should therefore be considered for any patient with suspected or known interstitial lung disease.

\section{Lung transplantation}

Lung transplant (LTx) represents the only treatment of proven benefit in IPF. In fact, in IPF patients lung transplant has been shown to reduce the risk of death by $75 \%$ as compared with patients who remain on the waiting list [74]. Since the introduction of the Lung Allocation Score (LAS), which prioritizes transplant candidates based on survival probability, IPF has become the most common indication for LTx in the United States. High LAS values are associated with decreased survival following lung transplantation, increased length of stay following transplantation, and higher rates of infection, renal failure and stroke [75]. Symptomatic patients with IPF younger than 65 years should be referred for lung transplantation if there is a $\mathrm{DL}_{\mathrm{CO}}<39 \%$ predicted and/ or evidence of a FVC decline $>10 \%$ over 6 months [76], but there are no clear data to guide the precise timing for LTx. Although controversial, the most recent data suggest that bilateral LTx is superior to single LTx in patients with IPF [77].

\section{Pulmonary rehabilitation}

Lack of energy and fatigue are common and disabling problems for patients with IPF. Pulmonary rehabilitation (PR) may alleviate symptoms and improve functional status by stabilizing and/or reversing the extrapulmonary features of the disease [78,79]. Typical PR programs include exercise training, nutritional modulation, occupational therapy, education and psychosocial counseling. Previous studies, in which physical training was compared to no physical training or other therapy, 
were not limited to patients with IPF, and included conditions potentially more amenable to the beneficial effect of PR. In a randomized-controlled trial on the effect of exercise-based PR in patients with ILD, including 34 with IPF, Holland and colleagues observed that the increase in 6MWD and the reduction in dyspnea and fatigue among IPF patients were not as remarkable as among the non-IPF patients. In addition, these benefits were seen immediately following training but not sustained 6 months after intervention [78]. With time IPF patients tend to discontinue any routine exercise due to increasing dyspnea. Whenever possible, this should be discouraged.

\section{Palliative care}

Although the key goal of treatment in IPF is to prevent disease progression, palliating symptoms such as dyspnea, chronic cough, depression and anxiety is equally important [80]. In addition, because the goal of maintaining a maximum level of wellness and quality of life requires the active patient participation, education about the disease and its course is another central component of care in IPF management. In this regard, psychosocial support through counseling or patient support groups is critical in addressing unique needs of patients with IPF.

In advanced disease dyspnea can be extremely distressing, thus impairing physical activity and quality of life. In selected cases of particularly severe dyspnea morphine could be considered. In a small case series Allen and colleagues reported that low dose diamorphine reduces dyspnea, anxiety and cough without significant decrease in oxygen saturation [81]. Further, oxygen therapy may be useful for palliation of dyspnea in hypoxemic patients. With disease progression patients may experience fear, anxiety and depression; psychological counseling and, in selected cases, pharmacological treatment should therefore be considered. In a recent cross-sectional study of outpatients with interstitial lung disease, including IPF, Ryerson and colleagues reported that depression score, functional status (as assessed by 4 minutes walk test) as well as pulmonary function all contribute to the severity of dyspnea [82]. Of note, this study shows that the relationship between dyspnea and depression is independent of other clinical variables, suggesting that treating depression (observed in as many as $23 \%$ of patients in this study) and functional status may improve dyspnea and quality of life.

Therapeutic challenges in IPF are summarized in Table 3.

\section{Conclusions}

The diagnosis and management of IPF represent a difficult task even for the most experienced clinicians. The disease should always be suspected in patients aged
Table 3 Therapeutic challenges in IPF

\begin{tabular}{l}
\hline Pharmacologic treatment \\
\hline Improving survival \\
\hline Treatment of concomitant conditions \\
\hline Management of acute exacerbations of IPF \\
\hline Non pharmacologic treatment \\
\hline Timely referral to a tertiary care center \\
\hline Pung transplantation \\
\hline Palliative care
\end{tabular}

$\geq 50$ years current or ex-smokers complaining of dry cough and dyspnea, particularly in the presence of compatible HRCT features [83]. However, the diagnosis may not be straightforward: HRCT features are typical ("definite" according to current guidelines) in only half of the cases, while biopsy-proven diagnoses are available in a minority of patients, even though histopathologic information has the greatest impact on the final diagnosis, particularly when the initial clinical/radiographic diagnosis is not IPF [6]. Early diagnosis would offer benefits to patients in terms of adequate information on the disease, timely referral for lung transplantation, avoidance of inappropriate drugs (e.g., steroids and immunosuppressive) [49], and enrollment in clinical trials. However, the symptoms of early IPF are often subtle, while ILD screening efforts are limited to subjects with known risk factors or with a history of familial IPF. How can we reduce diagnostic uncertainty? Recognition or suspicion (e.g., unexplained dyspnea) of IPF should prompt early referral to a specialty center. In fact, the diagnosis of IPF requires close collaboration between clinicians, radiologists, and pathologists experienced in ILD, and this is particularly relevant in cases in which the radiologic and histopathologic patterns are discordant (e.g., HRCT features inconsistent with UIP and histopathology showing UIP). Multidisciplinary specialist clinics and coordinated services can be only found in dedicated centers with highvolume ILD programs. Referral to centers with expertise may also allow participation in a clinical trial.

Management of IPF is similarly challenging. The only care options that are endorsed by current guidelines are lung transplantation and enrolment in a clinical trial [1]. In the past decade better understanding of the pathobiology of the disease has led to a dramatic increase in the number of therapies evaluated in IPF. Although participation in a clinical trial is not without risk, including side-effects from the drug under investigation, this option offers the patients the opportunity to play an active role in their own healthcare, gain access to new, potentially beneficial treatments as well as obtaining expert medical care at leading healthcare facilities [80]. In 
addition, clinical trials have provided crucial information about the natural history of the disease, and may guide subsequent study designs.

The goals of any disease management strategy include improving quality of life, helping patients to be more functional, reducing disease-related morbidity and complications or helping people to live longer. Given the absence of a proven, effective therapy a large degree of therapeutic nihilism has always surrounded the management of IPF. However, a more recent trend focusing on improving symptoms and quality of life in IPF patients has been gaining ground, and it is now widely accepted that palliative care should be a treatment priority and an integral and routine component of patients care [80].

Much work remains to be done in order to detect IPF in preclinical and early stages; nevertheless, the diagnostic accuracy has significantly increased by means of multidisciplinary discussion between clinicians, radiologists and pathologists with expertise in ILD. Similarly, and perhaps more importantly, recent clinical trials have shown promise in identifying treatment options. It is hoped that the results from ongoing and new clinical trials will soon determine an effective treatment for patients with this devastating disease.

\section{Abbreviations}

ACE: Angiotensin-converting enzyme; AE: Acute exacerbations; ANA: Antinuclear antibodies; BAL: Bronchoalveolar lavage; CAD: Coronary artery disease; COPD: Chronic obstructive pulmonary disease;

CTD: Connective tissue disease; $\mathrm{DL}_{\mathrm{co}}$ : Diffusing capacity of carbon monoxide; ET: Endothelin; FPF: Familial pulmonary fibrosis; FVC: Forced vital capacity; GERD: Gastroesophageal reflux disease; HP: Hypersensitivity pneumonitis; HRCT: High-resolution computed tomography; ILDs: Interstitial lung diseases; IPF: Idiopathic pulmonary fibrosis; LAS: Lung Allocation Score; LTX: Lung transplant; NAC: N-acetylcysteine; NSIP: Nonspecific interstitial pneumonitis; PAH: Pulmonary arterial hypertension; PH: Pulmonary hypertension PR: Pulmonary rehabilitation; 6MWD: 6-minute-walk distance; UIP: Usual interstitial pneumonia; VATS: Video-assisted thoracoscopy.

\section{Competing interests}

$L R$ reports receiving consulting fees from Boehringerlngelheim, Intermune, Celgene, Sanofi, Anthera and Gilead; lecture fees from Intermune. PS, RT, EC and AS have no conflict of interest to declare.

\section{Authors' contributions}

PS and LR conceived of the study and drafted the manuscript. RT, EC and AS participated in the design of the review and helped to draft the manuscript. All authors read and approved the final manuscript.

Received: 14 June 2012 Accepted: 31 October 2012 Published: 12 November 2012

\section{References}

1. Raghu G, Collard HR, Egan JJ, Martinez FJ, Behr J, Brown KK, et al: An official ATS/ERS/JRS/ALAT statement: idiopathic pulmonary fibrosis: evidencebased guidelines for diagnosis and management. Am J RespirCrit Care Med 2011, 15:788-824.

2. Bjoraker JA, Ryu JH, Edwin MK, Myers JL, Tazelaar HD, Schroeder DR, Offord KP: Prognostic significance of histopathologic subsets in idiopathic pulmonary fibrosis. Am J Respir Crit Care Med 1998, 157:199-203.

3. Flaherty KR, Toews GB, Travis WD, Colby TV, Kazerooni EA, Gross BH, Jain A, Strawderman RL 3rd, Paine R, Flint A, Lynch JP 3rd, Martinez FJ:
Clinical significance of histological classification of idiopathic interstitial pneumonia. Eur Respir J 2002, 19:275-283.

4. Nicholson AG, Colby TV, du Bois RM, Hansell DM, Wells AU: The prognostic significance of the histologic pattern of interstitial pneumonia in patients presenting with the clinical entity of cryptogenic fibrosingalveolitis. Am J Respir Crit Care Med 2000, 162:2213-2217.

5. King TE Jr, Schwarz Ml, Brown K, Tooze JA, Colby TV, Waldron JA Jr, Flint A, Thurlbeck W, Cherniack RM: Idiopathic pulmonary fibrosis: relationship between histopathologic features and mortality. Am J Respir Crit Care Med 2001, 164:1025-1032.

6. American Thoracic Society/European Respiratory Society International Multidisciplinary Consensus: Classification of the Idiopathic Interstitial Pneumonias. Am J Respir Crit Care Med 2002, 165:277-304.

7. King TE Jr: Clinical advances in the diagnosis and therapy of the interstitial lung diseases. Am J Respir Crit Care Med 2005, 172:268-279.

8. Collard HR, Tino G, Noble PW, Sheve MA, Michaels M, Carlson B, Schwarz Ml: Patient experiences with pulmonary fibrosis. Respir Med 2007, 101:1350-1354.

9. du Bois RM: An earlier and more confident diagnosis of idiopathic pulmonary fibrosis. Eur Respir Rev 2012, 21:141-146.

10. Cerri S, Spagnolo P, Luppi F, Richeldi L: Management of idiopathic pulmonary fibrosis. Clin Chest Med 2012, 33:85-94.

11. Nathan SD, Shlobin OA, Weir N, Ahmad S, Kaldjob JM, Battle E, Sheridan MJ, du Bois RM: Long-term course and prognosis of idiopathic pulmonary fibrosis in the new millennium. Chest 2011, 140:221-229.

12. Thomeer M, Demedts M, Behr J, Buhl R, Costabel U, Flower CD, Verschakelen J, Laurent F, Nicholson AG, Verbeken EK, Capron F, Sardina M, Corvasce G, Lankhorst I, Idiopathic Pulmonary Fibrosis International Group Exploring N-Acetylcysteine I Annual (IFIGENIA) study group: Multidisciplinary interobserver agreement in the diagnosis of idiopathic pulmonary fibrosis. Eur Respir J 2008, 31:585-591.

13. Flaherty KR, Andrei AC, King TE Jr, Raghu G, Colby TV, Wells A, Bassily N, Brown K, du Bois R, Flint A, Gay SE, Gross BH, Kazerooni EA, Knapp R, Louvar E, Lynch D, Nicholson AG, Quick J, Thannickal VJ, Travis WD, Vyskocil J, Wadenstorer FA, Wilt J, Toews GB, Murray S, Martinez FJ: Idiopathic interstitial pneumonia: do community and academic physicians agree on diagnosis? Am J Respir Crit Care Med 2007, 175:1054-1060.

14. Hodgson U, Laitinen T, Tukiainen P: Nationwide prevalence of sporadic and familial idiopathic pulmonary fibrosis: evidence of founder effect among multiplex families in Finland. Thorax 2002, 57:338-342.

15. Lee H, Ryu JH, Wittmer MH, Hartman TE, Lymp JF, Tazelaar HD, Limper AH: Familial idiopathic pulmonary fibrosis: clinical features and outcome. Chest 2005, 127:2034-2041.

16. Yang IV, Burch LH, Steele MP, Savov JD, Hollingsworth JW, McElvania-Tekippe E, Berman KG, Speer MC, Sporn TA, Brown KK, Schwarz MI, Schwartz DA: Gene expression profiling of familial and sporadic interstitial pneumonia. Am J Respir Crit Care Med 2007, 175:45-54.

17. Steele MP, Speer MC, Loyd JE, Brown KK, Herron A, Slifer SH, Burch LH, Wahidi MM, Phillips JA 3rd, Sporn TA, McAdams HP, Schwarz MI, Schwartz DA: Clinical and pathological features of familial interstitial pneumonia. Am J Respir Crit Care Med 2005, 172:1146-1152.

18. Costabel U, Bonella F, Guzman J: Chronic hypersensitivity pneumonitis. Clin Chest Med 2012, 33:151-163.

19. Ohshimo S, Bonella F, Cui A, Beume M, Kohno N, Guzman J, Costabel U: Significance of bronchoalveolar lavage for the diagnosis of idiopathic pulmonary fibrosis. Am J Respir Crit Care Med 2009, 179:1043-1047.

20. Lacasse $Y$, Selman M, Costabel U, Dalphin JC, Ando M, Morell F, Erkinjuntti-Pekkanen R, Muller N, Colby TV, Schuyler M, Cormier Y, HP Study Group: Clinical diagnosis of hypersensitivity pneumonitis. Am J Respir Crit Care Med 2003, 168:952-958.

21. Park JH, Kim DS, Park IN, Jang SJ, Kitaichi M, Nicholson AG, et al: Prognosis of fibrotic interstitial pneumonia: idiopathic versus collagen vascular disease-related subtypes. Am J Respir Crit Care Med 2007, 175:705-711.

22. Fischer A, West SG, Swigris JJ, Brown KK, du Bois RM: Connective tissue disease-associated interstitial lung disease: a call for clarification. Chest 2010, 138:251-256.

23. Fischer A, du Bois R: Interstitial lung disease in connective tissue disorders. Lancet 2012, 380:689-698.

24. Fischer A, Pfalzgraf FJ, Feghali-Bostwick CA, Wright TM, Curran-Everett D, West SG, Brown KK: Anti-th/to-positivity in a cohort of patients with idiopathic pulmonary fibrosis. J Rheumatol 2006, 33:1600-1605. 
25. Kishimoto T, Kato K, Arakawa H, Ashizawa K, Inai K, Takeshima Y: Clinical, radiological, and pathological investigation of asbestosis. Int J Environ Res Public Health 2011, 8:899-912.

26. Gaensler EA, Jederlinic PJ, Churg A: Idiopathic pulmonary fibrosis in asbestos-exposed workers. Am Rev Respir Dis 1991, 144:689-696.

27. Roggli VL, Gibbs AR, Attanoos R, Churg A, Popper H, Cagle P, Corrin B, Franks TJ, Galateau-Salle F, Galvin J, Hasleton PS, Henderson DW, Honma K Pathology of asbestosis- An update of the diagnostic criteria: Report of the asbestosis committee of the college of american pathologists and pulmonary pathology society. Arch Pathol Lab Med 2010, 134:462-480.

28. Clarke CC, Mowat FS, Kelsh MA, Roberts MA: Pleural plaques: a review of diagnostic issues and possible nonasbestos factors. Arch Environ Occup Health 2006, 61:183-192.

29. DeRemee RA: The roentgenographic staging of sarcoidosis. Historic and contemporary perspectives. Chest 1983, 83:128-133.

30. Scadding JG: Prognosis of intrathoracicsarcoidosis in England. A review of 136 cases after five years' observation. Br Med J 1961, 2:1165-1172.

31. Nobata K, Kasai T, Fujimura M, Mizuguchi M, Nishi K, Ishiura Y, Yasui M, Nakao S: Pulmonary sarcoidosis with usual interstitial pneumonia distributed predominantly in the lower lung fields. Intern Med 2006, 45:359-362.

32. Padley SP, Padhani AR, Nicholson A, Hansell DM: Pulmonary sarcoidosis mimicking cryptogenic fibrosingalveolitis on CT. Clin Radio/ 1996, 51:807-810.

33. Criado E, Sánchez M, Ramírez J, Arguis P, de Caralt TM, Perea RJ, Xaubet A: Pulmonary sarcoidosis: typical and atypical manifestations at highresolution CT with pathologic correlation. Radiographics 2010, 30:1567-1586.

34. Hendrick DJ, Blackwood RA, Black JM: Chest pain in the presentation of sarcoidosis. Br J Dis Chest 1976, 70:206-210.

35. Spagnolo P, Luppi F, Roversi P, Cerri S, Fabbri LM, Richeldi L: Sarcoidosis: challenging diagnostic aspects of an old disease. Am J Med 2012, 125:118-125.

36. Baughman RP, Nagai S, Balter M, Costabel U, Drent M, du Bois R, Grutters JC, Judson MA, Lambiri I, Lower EE, Muller-Quernheim J, Prasse A, Rizzato G, Rottoli P, Spagnolo $P$, Teirstein A: Defining the clinical outcome status (COS) in sarcoidosis: results of WASOG Task Force. Sarcoidosis Vasc Diffuse Lung Dis 2011, 28:56-64.

37. Sverzellati N, Wells AU, Tomassetti S, Desai SR, Copley SJ, Aziz ZA, Zompatori M, Chilosi M, Nicholson AG, Poletti V, Hansell DM: Biopsy-proved idiopathic pulmonary fibrosis: spectrum of nondiagnostic thin-section CT diagnoses. Radiology 2010, 254:957-964.

38. Ley B, Collard HR, King TE Jr: Clinical course and prediction of survival in idiopathic pulmonary fibrosis. Am J Respir Crit Care Med 2011, 183:431-440.

39. Sakamoto K, Taniguchi H, Kondoh Y, Ono K, Hasegawa Y, Kitaichi M: Acute exacerbation of idiopathic pulmonary fibrosis as the initial presentation of the disease. Eur Respir Rev 2009, 18:129-132.

40. Collard HR, Moore BB, Flaherty KR, Brown KK, Kaner RJ, King TE Jr, et al: Idiopathic Pulmonary Fibrosis Clinical Research Network Investigators. Acute exacerbations of idiopathic pulmonary fibrosis. Am J Respir Crit Care Med 2007, 176:636-643.

41. Monaghan H, Wells AU, Colby TV, du Bois RM, Hansell DM, Nicholson AG: Prognostic implications of histologic patterns in multiple surgical lung biopsies from patients with idiopathic interstitial pneumonias. Chest 2004, 125:522-526.

42. Flaherty KR, Travis WD, Colby TV, Toews GB, Kazerooni EA, Gross BH, Jain A, Strawderman RL, Flint A, Lynch JP, Martinez FJ: Histopathologic variability in usual and nonspecific interstitial pneumonias. Am J Respir Crit Care Med 2001, 164:1722-1727

43. Kreider ME, Hansen-Flaschen J, Ahmad NN, Rossman MD, Kaiser LR, Kucharczuk JC, Shrager JB: Complications of video-assisted thoracoscopic lung biopsy in patients with interstitial lung disease. Ann Thorac Surg 2007, 83:1140-1145.

44. Raghu G, Collard HR, Anstrom KJ, Flaherty KR, Fleming TR, TE King JR, Martinez FJ, Brown KK: Idiopathic pulmonary fibrosis: clinically meaningful primary endpoints in phase 3 clinical trials. Am J Respir Crit Care Med 2012, 185:1044-1048

45. Luppi F, Spagnolo P, Cerri S, Richeldi L: The big clinical trials in idiopathic pulmonary fibrosis. Curr Opin Pulm Med 2012, 18:428-432.

46. Demedts M, Behr J, Buhl R, Costabel U, Dekhuijzen R, Jansen HM, et al: High-dose acetylcysteine in idiopathic pulmonary fibrosis. $N$ Engl J Med 2005, 353:2229-2242.
47. Kubo H, Nakayama K, Yanai M, Suzuki T, Yamaya M, Watanabe M, Sasaki H: Anticoagulant therapy for idiopathic pulmonary fibrosis. Chest 2005, 128:1475-1482.

48. Noth I, Anstrom KJ, Calvert SB, de Andrade J, Flaherty KR, Glazer C, Kaner RJ, Olman MA: Idiopathic Pulmonary Fibrosis Clinical Research Network (IPFnet). A placebo-controlled randomized trial of warfarin in idiopathic pulmonary fibrosis. Am J Respir Crit Care Med 2012, 186:88-95.

49. The Idiopathic Pulmonary Fibrosis Clinical Research Network, Raghu G Anstrom KJ, King TE Jr, Lasky JA, Martinez FJ: Prednisone, azathioprine, and N-acetylcysteine for pulmonary fibrosis. N Engl J Med 2012, 366:1968-1977.

50. du Bois RM, Weycker D, Albera C, Bradford WZ, Costabel U, Kartashov A, King TE Jr, Lancaster L, Noble PW, Sahn SA, Thomeer M, Valeyre D, Wells AU: Forced vital capacity in patients with idiopathic pulmonary fibrosis: test properties and minimal clinically important difference. Am J Respir Crit Care Med 2011, 184:1382-1389.

51. Richeldi L, Costabel U, Selman M, Kim DS, Hansell DM, Nicholson AG, Brown KK, Flaherty KR, Noble PW, Raghu G, Brun M, Gupta A, Juhel N, Klüglich M, du Bois RM: Efficacy of a tyrosine kinase inhibitor in idiopathic pulmonary fibrosis. N Engl J Med 2011, 365:1079-1087.

52. Boyd CM, Weiss CO, Halter J, Han KC, Ershler WB, Fried LP: Framework for evaluating disease severity measures in older adults with comorbidity. J Gerontol A Biol Sci Med Sci 2007, 62:286-295.

53. Lettieri CJ, Nathan SD, Barnett SD, Ahmad S, Shorr AF: Prevalence and outcomes of pulmonary arterial hypertension in advanced idiopathic pulmonary fibrosis. Chest 2006, 129:746-752.

54. Cottin V, Le Pavec J, Prévot G, Mal H, Humbert M, Simonneau G, Cordier JF: GERM"O"P Pulmonary hypertension in patients with combined pulmonary fibrosis and emphysema syndrome. Eur Respir J 2010, 35:105-111.

55. Judge EP, Fabre A, Adamali HI, Egan JJ: Acute exacerbations and pulmonary hypertension in advanced idiopathic pulmonary fibrosis. Eur Respir J 2012, 40:93-100.

56. Collard HR, Anstrom KJ, Schwarz MI, Zisman DA: Sildenafil improves walk distance in idiopathic pulmonary fibrosis. Chest 2007, 131:897-899.

57. Zisman DA, Schwarz M, Anstrom KJ, Collard HR, Flaherty KR, Hunninghake GW: A controlled trial of sildenafil in advanced idiopathic pulmonary fibrosis. N Engl J Med 2010, 363:620-628.

58. King TE Jr, Behr J, Brown KK, du Bois RM, Lancaster L, de Andrade JA, Stähler G, Leconte I, Roux S, Raghu G: BUILD-1: a randomized placebocontrolled trial of bosentan in idiopathic pulmonary fibrosis. Am J Respir Crit Care Med 2008, 177:75-81.

59. King TE Jr, Brown KK, Raghu G, du Bois RM, Lynch DA, Martinez F, Valeyre D, Leconte I, Morganti A, Roux S, Behr J: BUILD-3: a randomized, controlled trial of bosentan in idiopathic pulmonary fibrosis. Am J Respir Crit Care Med 2011, 184:92-99.

60. Raghu G, Freudenberger TD, Yang S, Curtis JR, Spada C, Hayes J, Sillery JK, Pope CE 2nd, Pellegrini CA: High prevalence of abnormal acid gastrooesophageal reflux in idiopathic pulmonary fibrosis. Eur Respir J 2006, 27:136-142.

61. Lee JS, Collard HR, Raghu G, Sweet MP, Hays SR, Campos GM, Golden JA King TE Jr: Does chronic microaspiration cause idiopathic pulmonary fibrosis? Am J Med 2010, 123:304-331.

62. Lee JS, Ryu JH, Elicker BM, Lydell CP, Jones KD, Wolters PJ, et al: Gastroesophageal reflux therapy is associated with longer survival in patients with idiopathic pulmonary fibrosis. Am J Respir Crit Care Med 2011, 184:1390-1394

63. Hubbard RB, Smith C, Le Jeune I, Gribbin J, Fogarty AW: The association between idiopathic pulmonary fibrosis and vascular disease: a population-based study. Am J Respir Crit Care Med 2008, 178:1257-1261.

64. Nathan SD, Basavaraj A, Reichner C, Shlobin OA, Ahmad S, Kiernan J, Burton N, Barnett SD: Prevalence and impact of coronary artery disease in idiopathic pulmonary fibrosis. Respir Med 2010, 104:1035-1041.

65. Noble PW, Albera C, Bradford WZ, Costabel U, Glassberg MK, Kardatzke D, King TE Jr, Lancaster L, Sahn SA, Szwarcberg J, Valeyre D, du Bois RM, CAPACITY Study Group: Pirfenidone in patients with idiopathic pulmonary fibrosis (CAPACITY): two randomised trials. Lancet 2011, 377:1760-1769.

66. King TE Jr, Albera C, Bradford WZ, Costabel U, Hormel P, Lancaster L, Noble PW, Sahn SA, Szwarcberg J, Thomeer M, Valeyre D, du Bois RM, INSPIRE Study Group: Effect of interferon gamma-1b on survival in patients with idiopathic pulmonary fibrosis (INSPIRE): a multicentre, randomised, placebo-controlled trial. Lancet 2009, 374:222-228. 
67. Agarwal R, Jindal SK: Acute exacerbation of idiopathic pulmonary fibrosis: a systematic review. Eur J Intern Med 2008, 19:227-235.

68. Stern JB, Mal H, Groussard O, Brugiere O, Marceau A, Jebrak G, Fournier M: Prognosis of patients with advanced idiopathic pulmonary fibrosis requiring mechanical ventilation for acute respiratory failure. Chest 2001, 120:213-219.

69. Blivet S, Philit F, Sab JM, Langevin B, Paret M, Guerin C, Robert D: Outcome of patients with idiopathic pulmonary fibrosis admitted to the ICU for respiratory failure. Chest 2001, 120(70):209-212.

70. Saydain G, Islam A, Afessa B, Ryu JH, Scott JP, Peters SG: Outcome of patients with idiopathic pulmonary fibrosis admitted to the intensive care unit. Am J Respir Crit Care Med 2002, 166:839-842.

71. Rangappa P, Moran JL: Outcomes of patients admitted to the intensive care unit with idiopathic pulmonary fibrosis. Crit Care Resusc 2009, 11:102-109.

72. Lamas DJ, Kawut SM, Bagiella E, Philip N, Arcasoy SM, Lederer DJ: Delayed access and survival in idiopathic pulmonary fibrosis: a cohort study. Am J Respir Crit Care Med 2011, 184:842-847.

73. Hosenpud JD, Bennett LE, Keck BM, Edwards EB, Novick RJ: Effect of diagnosis on survival benefit of lung transplantation for end-stage lung disease. Lancet 1998, 351:24-27.

74. Thabut G, Mal H, Castier Y, Groussard O, Brugière O, Marrash-Chahla R, Lesèche $G$, Fournier M: Survival benefit of lung transplantation for patients with idiopathic pulmonary fibrosis. J Thorac Cardiovasc Surg 2003, 126:469-475.

75. Russo MJ, Iribarne A, Hong KN, Davies RR, Xydas S, Takayama H, Ibrahimiye A, Gelijns AC, Bacchetta MD, D'Ovidio F, Arcasoy S, Sonett JR: High lung allocation score is associated with increased morbidity and mortality following transplantation. Chest 2010, 137:651-657.

76. Orens JB, Estenne M, Arcasoy S, Conte JV, Corris P, Egan JJ, et al: International guidelines for the selection of lung transplant candidates: 2006 update - a consensus report from the Pulmonary Scientific Council of the International Society for Heart and Lung Transplantation. $J$ Heart Lung Transplant 2006, 25:745-755.

77. George TJ, Arnaoutakis GJ, Shah AS: Lung transplant in idiopathic pulmonary fibrosis. Arch Surg 2011, 146:1204-1209.

78. Holland AE, Hill CJ, Conron M, Munro P, McDonald CF: Short term improvement in exercise capacity and symptoms following exercise training in interstitial lung disease. Thorax 2008, 63:549-554.

79. Nishiyama O, Kondoh Y, Kimura T, Kato K, Kataoka K, Ogawa T, Watanabe F, Arizono S, Nishimura K, Taniguchi H: Effects of pulmonary rehabilitation in patients with idiopathic pulmonary fibrosis. Respirology 2008, 13:394-399.

80. Lee JS, McLaughlin S, Collard HR: Comprehensive care of the patient with idiopathic pulmonary fibrosis. Curr Opin Pulm Med 2011, 17:348-354.

81. Allen S, Raut S, Woollard J, Vassallo M: Low dose diamorphine reduces breathlessness without causing a fall in oxygen saturation in elderly patients with end-stage idiopathic pulmonary fibrosis. Palliat Med 2005, 19:128-130

82. Ryerson CJ, Berkeley J, Carrieri-Kohlman VL, Pantilat SZ, Landefeld CS, Collard HR: Depression and functional status are strongly associated with dyspnea in interstitial lung disease. Chest 2011, 139:609-616.

83. Fell CD, Martinez FJ, Liu LX, Murray S, Han MK, Kazerooni EA, Gross BH, Myers J, Travis WD, Colby TV, Toews GB, Flaherty KR: Clinical predictors of a diagnosis of idiopathic pulmonary fibrosis. Am J Respir Crit Care Med 2010, 181:832-837.

doi:10.1186/2049-6958-7-42

Cite this article as: Spagnolo et al:: Idiopathic pulmonary fibrosis: diagnostic pitfalls and therapeutic challenges. Multidisciplinary Respiratory Medicine 2012 7:42.

\section{Submit your next manuscript to BioMed Central and take full advantage of:}

- Convenient online submission

- Thorough peer review

- No space constraints or color figure charges

- Immediate publication on acceptance

- Inclusion in PubMed, CAS, Scopus and Google Scholar

- Research which is freely available for redistribution

Submit your manuscript at www.biomedcentral.com/submit
Ciomed Central 